\title{
VOLUME GRATING RECORDING IN ACRYLATE-BASED PHOTOPOLYMERS
}

\author{
J. Aleksejeva, J. Teteris \\ Institute of Solid State physics University of Latvia, \\ Kengaraga street 8, Riga, LV-1063, LATVIA
}

\begin{abstract}
Norland Optical Adhesive (NOA) acrylate-based photopolymers were studied as a material for fabrication of volume gratings. Photopolymers were irradiated by a $\mathrm{He}-\mathrm{Cd}$ laser of $325 \mathrm{~nm}$ line interference pattern during holographic recording. We recorded transmission and reflection holograms. The formation of grating in photopolymers can be explained by photopolymerization during the UV light irradiance. Diffraction efficiency in dependence on the sample thickness and on the polarization state/intensity of recording beam was investigated in the transmission mode. To achieve a better angular selectivity of the diffracted beam, the thickness of the prepared samples was raised up to $2.4 \mathrm{~mm}$. In this work the diffraction efficiency $>80 \%$ was achieved. The best angular selectivity of a diffracted beam was several minutes. Gratings with high diffraction efficiency and good angular selectivity can successfully be used in the telecommunications and data storage devices. The advantages of such a grating are long-term mechanical stability, low dependence on the temperature changes as well as simple and cheap preparation.

Key words: volume grating, NOA photopolymer, angular selectivity, holographic recording.
\end{abstract}

\section{INTRODUCTION}

Photopolymers are promising materials for the holographic and lithographic fabrication of optical elements. They can successfully be used in optical storage devices, optical elements and interconnections. Nowadays, photopolymers such as acrylate solid photopolymer films, acrylamide-based compositions, phenanthrenequinone-dye doped poly(methyl-methacrylate), multicomponent acrylate oligomermonomer and oligomer-diluents liquid mixtures, and polymers containning azobenzene moieties, are intensively investigated as materials for holographic recording [1-5].

Photopolymers are photosensitive materials, which change their intrinsic properties during UV light irradiation. The composition of a photopolymer layer usually consists of a photosensitizer, an electron donor or initiator, monomer molecules, and a polymer binder acting like a matrix in which the other components are suspended. As a polymer binder, polymethylacrylate (PMMA) is often used, and monomer molecules in photopolymers are usually formed by acrylates. The UV light radiation initiates a photopolymerization process in photopolymers. The acrylate monomers contain a vinyl group formed by two carbon atoms bound by a double chemical bond and in that way enabling the start of polymer formation by absorbing UV light. The UV photon is absorbed by photosensitizer - a photo- 
polymer component. This former becomes excited and reacts with the electron donor. In this reaction the electron donor loses one electron and becomes positively charged, while the photosensitizer obtains one unmatched electron and becomes negatively charged. The charged electron donor then loses a proton and forms a free radical, which, in the presence of monomer, initiates the photopolymerization process. Due to polymerization there are significant changes in material properties - the density and the molecular polarizability are changing, which, in turn, causes changes in the refractive index $[3,4,6]$. If the photopolymer is illuminated in an appropriate wavelength interference pattern, the photopolymerization occurs in the illuminated area, whereas in the non-illuminated area there are no changes in the material properties and composition. The periodical changes in the refractive index are stored, which allows recording a volume grating in the photopolymer. During the holographic recording in an illuminated area the material shrinks, which is undesirable in the volume grating fabrication. For this reason in this work the photopolymers with a low shrinkage index were used. These photopolymers (Norland Optical Adhesive (NOA) photopolymers) are produced by Norland Products and are commercially available. In this work, NOA 60, NOA 61, NOA 63, NOA 65 and NOA 68 photopolymers were studied.

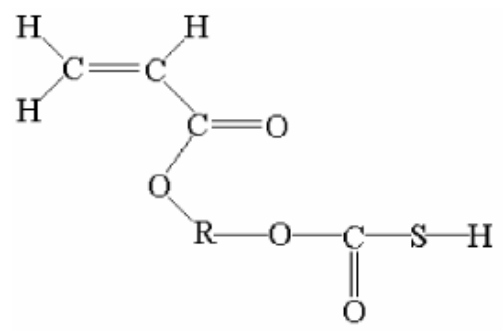

Fig. 1. The mercaptoester structure.

NOA photopolymers contain acrylate monomers, which are bound with mercaptoester. Mercaptans are the alcohol equivalent, but the hydroxyl $(-\mathrm{OH})$ is changed by the sulphur group (-SH). An advantage of the mercaptans is that they are less sensitive to the speed of curing the material. Thus, they can also be successfully used in curing thin films.

The NOA photopolymers also have a low viscosity $\left(300-5000 \mathrm{cps}\right.$ at $\left.25^{\circ} \mathrm{C}\right)$, which provides a faster curing.

\section{EXPERIMENTAL}

The samples were prepared in two steps. First, the photopolymer was sandwiched between two glasses. On the edges of glass for controlling the sample thickness a spacer was placed. Second, the edges of a sample were irradiated with a Xe lamp (the UV radiation spectrum), thus the photopolymer on the edges was cured and became rigid. After that the glasses could not be separated from each other. This provided stable samples, which were ready for the use. The exposition time was varied for different samples. Since the curing time depends on the sample thickness, this was ranged from $160 \mu \mathrm{m}$ to $2400 \mu \mathrm{m}$ for making volume gratings during holographic recording. 


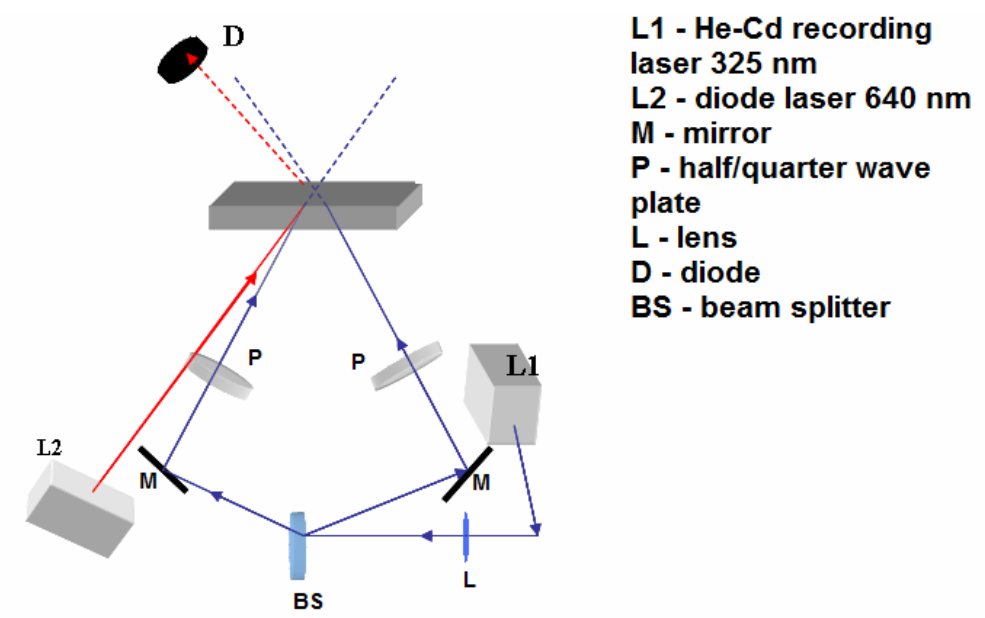

Fig. 2. Experimental setup for creation of volume gratings during holographic recording.

The experimental setup is shown in Fig. 2. It was formed in such a way that a sample during recording was in the horizontal position. A He-Cd laser beam with $325 \mathrm{~nm}$ wavelength was used as the light source for holographic recording. The laser beam was expanded by telescope $L$. After expansion the laser beam was split by a beam splitter into two beams of equal intensity crossed on the surface of the sample. Between the mirrors and the sample, half- or quarter-wave plates were placed for controlling the polarization state of the recording beams. The angle between the recording beam and the normal was $\theta=14^{\circ}$. According to the Bragg law, this allows a grating with period $\Lambda=0.67 \mu \mathrm{m}$ to be recorded. The NOA photopolymers are absolutely transparent for the visible spectrum; thus, as a reading beam source a diode laser with $640 \mathrm{~nm}$ wavelength was used. The diode laser beam was positioned at a Bragg angle, which can be calculated according to the Bragg law:

$$
\theta=\arcsin \left(\frac{\lambda}{2 \Lambda}\right)
$$

During the recording, the beam diffraction was measured in the transmission mode by a PC-connected photodiode.

\section{RESULTS AND DISCUSSION}

First of all, the dependence of diffraction efficiency on the polarization state of recording beams was studied (Fig. 3). With half-wave plates the $s s, p p$ and $45^{\circ} / 45^{\circ}$ linear polarization states were set. The $p p$ polarization state is formed by linearly polarized light whose electrical vector oscillates perpendicularly to the grating lines; the ss polarization state is formed by a linearly polarized light with the electrical vector oscillating parallel to the grating lines. In the case of $-45^{\circ} / 45^{\circ}$ states the polarization direction of the recording beams forms $-45^{\circ}$ and $+45^{\circ}$ angles with the plane of the holographic setup; thus, the recording beams are orthogonal, with no interference pattern formed by the light intensity modulation on the sample surface. Instead, there is modulation of the polarization direction [7]. The leftleft/right-right (LL/RR) circular polarization states were set with quarter-wave 
plates. For each volume grating recording the equal exposition $\left(1 \mathrm{~J} / \mathrm{cm}^{2}\right)$ was used. The results show that the $p p$ and $s s$ polarization gives similar diffraction efficiency values. The LL/RR circular polarization gives worse results, while at the use of $-45^{\circ} / 45^{\circ}$ polarization the grating was not recorded at all. For further experiments the ss polarization state for recording beams was chosen.

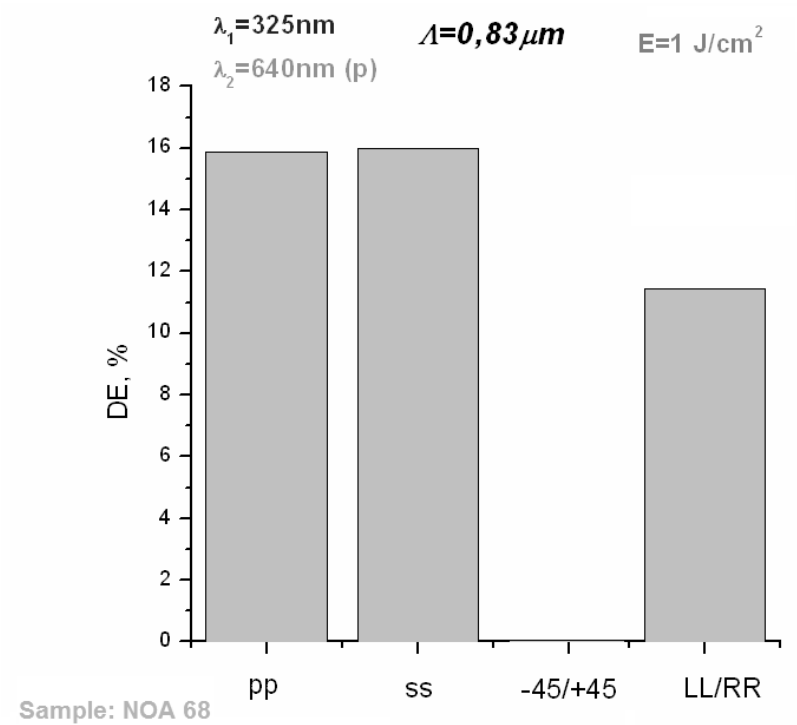

Fig. 3. Diffraction efficiency dependence on the recording beams polarization state.

According to [8], the diffraction efficiency of transmission thick phase grating depends on the refractive index modulation during holographic recording. This is described by the following equation:

$$
\eta(t)=\frac{I_{D}(t)}{I_{\text {in }}}=\sin ^{2}\left[\frac{\pi n(t) d}{\lambda \cos \theta}\right]
$$

where $I_{\text {in }}$ and $I_{D}(t)$ are the incident and diffracted probe beam intensities, respectively;

$d \quad$ is the grating thickness;

$\theta$ and $\lambda \quad$ are the Bragg angle and wavelength of the incident probe beam inside the grating;

$n(t) \quad$ is the refractive index modulation.

In Fig. 4 the kinetics of recording is shown, which depends on the thickness of a sample. The kinetics in Fig. $4 a$ characterizes the samples with a thickness of $160-250 \mu \mathrm{m}$. The diffraction efficiency reaches the maximum in some minutes, after which the DE changes are not considerable or there is no changes at all. This means that the refraction index of photopolymer is changing in illuminated areas only during the first minutes of recording. In non-illuminated areas there are no changes in the refraction index during all the time of the recording. When the reading beam is going through such a grating, the speed of light in the areas illuminated by interference pattern differs from the speed in non-illuminated areas. 

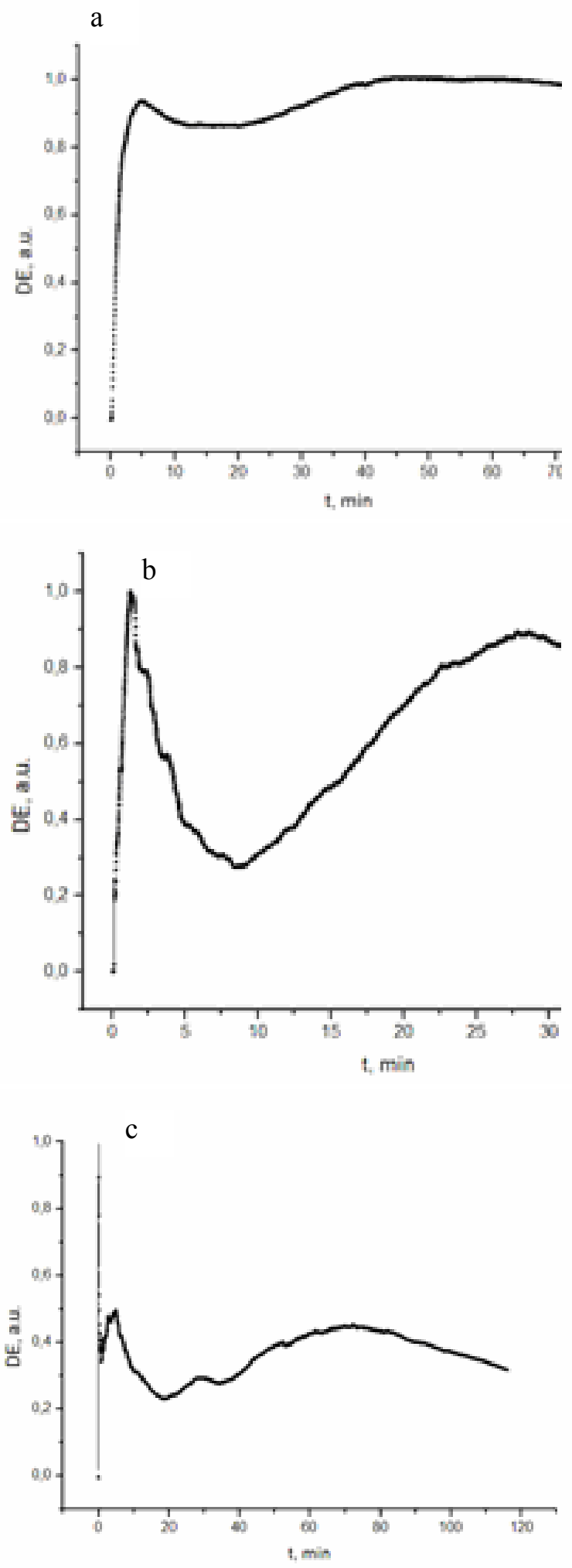

Fig. 4. Kinetics of recording in samples with different thickness $d$ : a) $d=160-250 \mu \mathrm{m} ; b) d=250-500 \mu \mathrm{m} ; c$ ) $d>500 \mu \mathrm{m}$. 
This produces a phase shift, which affects the diffraction efficiency. In Fig. $4 a$ the phase shift is up to a half-wave. Figure $4 b$ presents the holographic recording kinetics of $250-500 \mu \mathrm{m}$ thick samples. The diffraction efficiency reaches the maximum faster than in the case of thinner samples; still, 1-2 minutes are required. The decrease in the DE follows the first maximum, after which it starts growing again. The appearance of the second maximum depends on the thickness of a sample and the photopolymer compound. The phase shift in those samples could be above one wavelength. Figure $4 c$ graph shows the kinetics of the samples with a thickness greater than $500 \mu \mathrm{m}$. The diffraction efficiency reaches the maximum in the first seconds of the recording, then fast DE falling follows, after which the DE is changing periodically. This means that in the case of thicker samples the phase shift is several wavelengths. Thus, the photopolymerization process in a thicker layer is slower. The recording beam is partially absorbed by photopolymer, and the light intensity starts decreasing when the beam is going through the sample. Therefore, the upper layer of the photopolymer is illuminated with greater intensity and receives greater exposition. Due to this, the kinetics of grating formation becomes more complicated.

We studied the volume grating recording in different NOA photopolymers. The gratings were recorded under identical conditions: the sample thickness $270 \pm 20 \mu \mathrm{m}$, and the intensity of each recording beam $6.6 \mathrm{~mW}$. The results are shown in Table 1. In the third column, $\alpha$ is the angle between the maximum value of diffracted beam and the half of that value. This provides information about the angular selectivity of a grating. The results show the dependence of diffraction efficiency on the concentration of monomers (see Table 1). Increasing the mercaptoester concentration leads to the increase in the maximum value of diffraction efficiency. The angular selectivity also possesses a strong dependence on the composition of a photopolymer [2.].

Table 1

Recording in different NOA photopolymers

\begin{tabular}{|c|c|c|c|}
\hline $\begin{array}{c}\text { Mercaptoester } \\
\text { concentration, } \%\end{array}$ & NOA & $\alpha^{\prime}$ & $\mathrm{DE}_{\max }, \%$ \\
\hline $20-50$ & 65 & $8^{\prime}$ & 11 \\
\hline $40-50$ & 63 & $13^{\prime}$ & 23 \\
\hline $55-60$ & 61 & $20^{\prime}$ & 26 \\
\hline $40-60$ & 60 & $9^{\prime}$ & 28 \\
\hline $45-65$ & 68 & $12^{\prime}$ & 39.5 \\
\hline
\end{tabular}

The best angular selectivity was obtained using NOA 65. This was the reason for using it in further experiments, despite the fact that this photopolymer has the lowest diffraction efficiency.

In our experiments, we observed a holographic recording dependence on the thickness of NOA 65 samples. Using different spacers we prepared samples of different thickness. In this case the intensity of each recording beam was $5.5 \mathrm{~mW}$. 
Recording dependence on the sample thickness

\begin{tabular}{|c|c|c|c|c|}
\hline$d, \mu \mathrm{m}$ & $\begin{array}{c}\mathrm{DE}_{\max }, \% \\
640 \mathrm{~nm}\end{array}$ & $\begin{array}{c}\mathrm{DE}_{\mathrm{f}}, \% \\
640 \mathrm{~nm}\end{array}$ & $\begin{array}{c}\mathrm{DE}_{\mathrm{f}}, \% \\
448 \mathrm{~nm}\end{array}$ & $\alpha^{\prime}$ \\
\hline 160 & 28.6 & 25.8 & 69.3 & $17^{\prime}$ \\
\hline 190 & 34.5 & 29.6 & 65.0 & $16^{\prime}$ \\
\hline 270 & 43 & 36.7 & 62.7 & $12^{\prime}$ \\
\hline 830 & 22 & 7.6 & 13.7 & $15^{\prime}$ \\
\hline 2400 & 27.4 & 5.0 & 23.3 & $16^{\prime}$ \\
\hline
\end{tabular}

The results are shown in Table 2. In the second column the maximum diffraction efficiency is shown, which was measured during the recording by reading beam (a diode laser with $640 \mathrm{~nm}$ wavelength was used). In the third column the final diffraction efficiency is shown, which was measured by a reading beam at the end of experiment. In the fourth column the final diffraction efficiency of the same grating as in the third one is shown, but now the DE was measured using a semiconductor laser with $448 \mathrm{~nm}$ wavelength. For this purpose a recorded grating was placed on a rotational sample holder, so that the reading beam was set precisely at the Bragg angle. This measurement gives greater values of the final diffraction efficiency. The recorded grating had a good angular selectivity; for precise results the reading beam in the experimental setup should be placed within a minute of the angle accuracy. In this case the reading beam had some shift from Bragg's grating, therefore the measurement with a diode laser gives the information only on the kinetics of recording but not on the absolute diffraction efficiency values. Table 2 shows that increasing the thickness of a sample leads to increase in the diffraction efficiency and decrease in $\alpha$. At the same time, as seen in this table, thicker samples give contrary results; this could be explained by grating deformation during recording, which is caused by shrinkage of the photopolymer in the photopolymerization process. Although NOA photopolymers have low shrinkage index, the volume changes in such thick samples are noticeable.

To improve the angular selectivity, the grating deformation has to be prevented. This means that a photopolymer's shrinkage should be reduced. For this purpose, the $250 \mu \mathrm{m}$ sample before recording was irradiated with a Xe lamp for $30 \mathrm{~s}$ from each side, which provides uniform shrinkage along the whole sample during the photopolymerization process. The measurements show that under the same recording conditions the non-irradiated sample had $\alpha=16^{\prime}$, while the iradiated one $-\alpha=11^{\prime}$. The better angular selectivity is accompanied by a decrease in the diffraction efficiency by to $4 \%$.

For the sample irradiated by a Xe lamp for $30 \mathrm{~s}$ from each side, the time dependence of diffraction efficiency is shown in Fig. $5 a$ for different recording beam intensities. The measurements show that the exposition required for reaching the maximum diffraction efficiency is the same for different intensities of recording beams.

In the NOA 65 sample the self-enhancement process was investigated. 

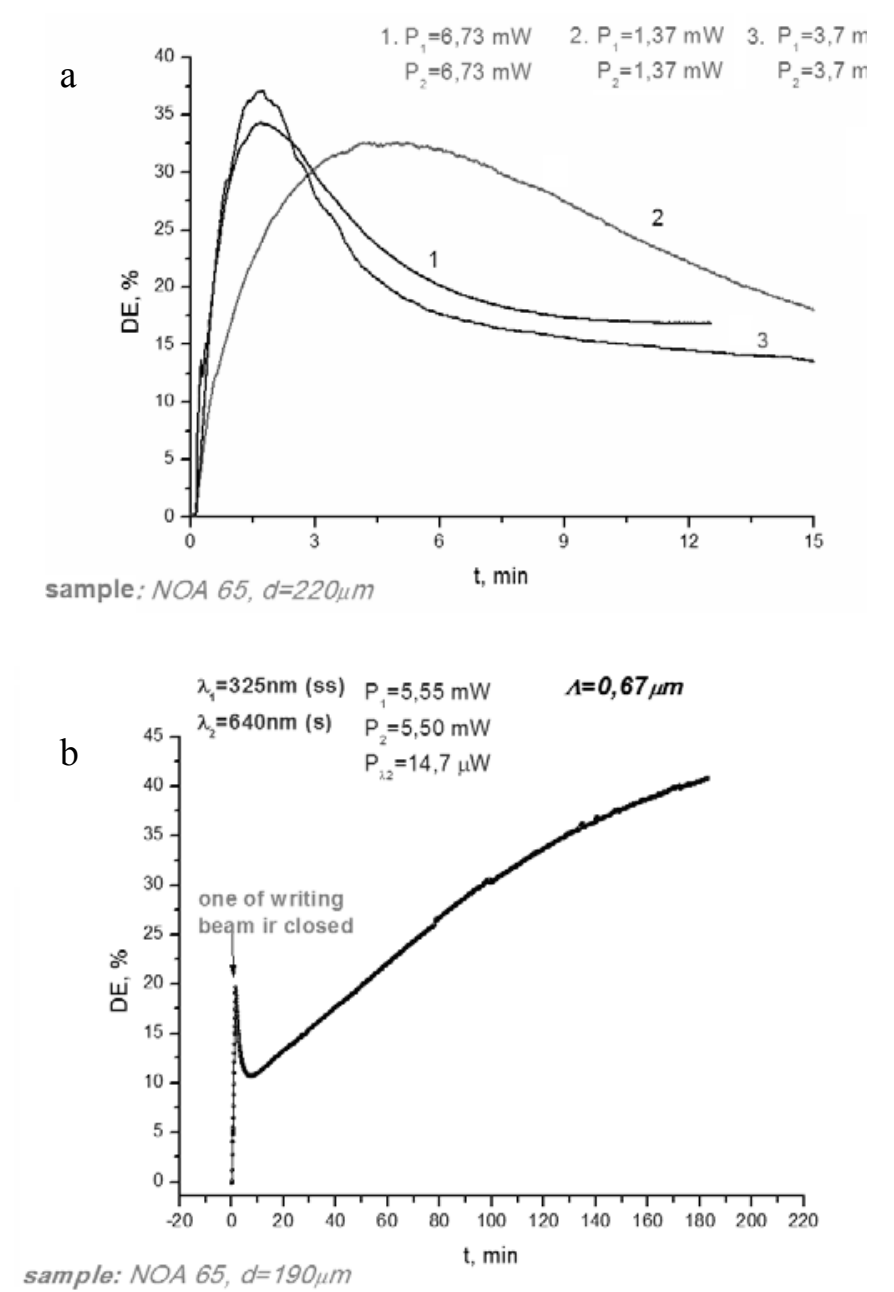

Fig. 5. $a$-Time dependence of diffraction efficiency of holographic recording. $b$ - Kinetics of self-enhancement process.

First, a grating is recorded by two recording beams; then one of them is switched off. The self-enhancement process takes place when only one of the recording beams is recording a grating. The interference pattern in this case is made by the recording beam and its diffracted beam.

The parameters of self-enhancement process

\begin{tabular}{|c|c|c|c|c|}
\hline $\begin{array}{l}\mathrm{DE}_{\mathrm{o}}, \% \\
640 \mathrm{~nm}\end{array}$ & $\begin{array}{l}\mathrm{DE}_{\mathrm{f}}, \% \\
640 \mathrm{~nm}\end{array}$ & $\begin{array}{l}\mathrm{DE}_{\mathrm{f}}, \% \\
448 \mathrm{~nm}\end{array}$ & $\xi$ & $\alpha^{\prime}$ \\
\hline 11.1 & 11.8 & 48.6 & 1.1 & 16 \\
\hline 14.3 & 30.9 & 58.9 & 2.2 & 11 \\
\hline 19.6 & 41 & 82 & 2.1 & 13 \\
\hline 22.4 & 33.5 & 73.2 & 1.5 & 11 \\
\hline
\end{tabular}

The thickness of the sample was $190 \mu \mathrm{m}$, and the intensity of each recording was $5.5 \mathrm{~mW}$. The results are shown in Table 3. Although the self-enhancement 
index $\xi$ is not large, we have succeeded in achievement of good diffraction efficiency. In that sample in the mentioned conditions the volume grating to $\mathrm{DE}_{\mathrm{o}}$ was recorded. Then one of the recording beams was switched off. As the kinetics of self-enhancement process shows (Fig. $5 b$ ), after that the diffraction efficiency is falling. This can be explained by fast changes of the refraction index between illuminated and non-illuminated areas in the grating. After a short-term decline, the diffraction efficiency starts to grow and reaches the maximum $\mathrm{DE}_{\mathrm{f}}$, which was measured after recording with a $448 \mathrm{~nm}$ semiconductor laser on a rotational sample holder. The best measured result was $82 \%$ in the transmission mode, and the angular selectivity of this grating was $13^{\prime}$.

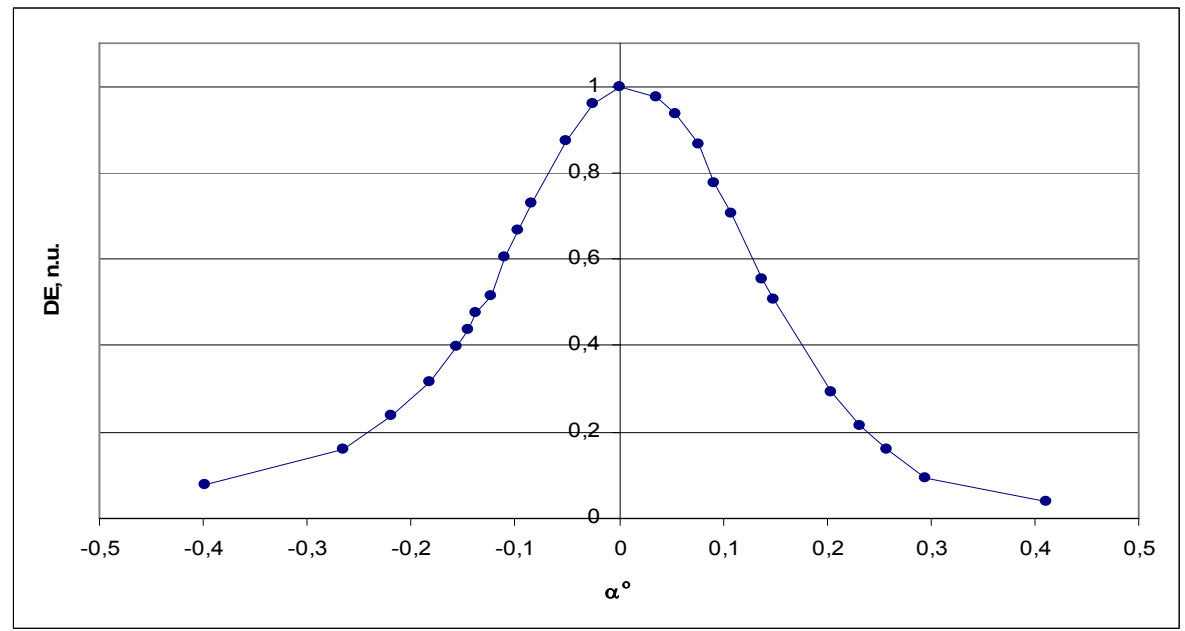

Fig. 6. Dependence of the diffraction efficiency of recording on the Bragg angle deviation.

In Fig. 6 the profile of the diffracted beam is shown. It was measured by a goniometer using a Verdi laser with $532 \mathrm{~nm}$ wavelength. In this case $\alpha$ is $9^{\prime}$. During the measurement, in order to change the angle of incidence the sample was turned off the laser beam direction, which could cause the profile extension on the right side seen in the figure.

\section{CONCLUSION}

The research shows that the NOA photopolymers are a promising material for volume grating formation during holographic recording by UV light. Our experiments have shown that in such photopolymers it is possible to record a volume grating with high diffraction efficiency $(82 \%)$ in the transmission mode. A large thickness of the sample allows a good angular selectivity ( $8 \mathrm{~min}$.) to be reached.

\section{REFERENCES}

1. Pavani, K., Naydenova, I., Martin, S., \& Toal, V. (2007). Photoinduced surface relief studies in an acrylamide-based photopolymer. J. Opt. A: Pure Appl. Opt., 9, 43-48. Doi:10.1088/1464-4258/9/1/008

2. Ching-Cherng Sun, Chih-Yuan Hsu, Shih-Hsin Ma, \& Wei-Chia Su (2007). Rotation selectivity of random phase encoding in volume holograms. Optics Communications, 276, 62-66. 
3. Calvo1, M.L., \& Cheben, P. (2009). Photopolymerizable sol-gel nanocomposites for holographic recording. J. Opt. A: Pure Appl. Opt., 11, 024009 (11). Doi:10.1088/14644258/11/2/024009

4. Lawrence, J.R., O’Neill, F.T., \& Sheridan, J.T. (2001). Photopolymer holographic recording material. Optik, 2 (10), 449-463.

5. Pinto-Iguanero, B., Olivares-Perez, A., \& Fuentes-Tapia, I. (2002). Holographic material film composed by Norland Noa 65 adhesive. Optical Materials, 20, 225-232.

6. Gleeson, M.R., \& Sheridan, J. T. (2009). A review of the modelling of free-radical photopolymerization in the formation of holographic gratings. J. Opt. A: Pure Appl. Opt., 11. 024008 (12). Doi:10.1088/1464-4258/11/2/024008.

7. Jing-Heng Chen, \& Der-Chin Su (2003). Holographic spatial walk-off polarizer and its application to a 4-port polarization-independent optical circulator. Optics Express, 2003, 11, (17), 2001-2006.

8. Kogelnik, H. (1969). Coupled wave theory for thick hologram gratings. Bell Syst. Tech. J., 48, 290-2947.

\section{TILPUMA REŽGUU IERAKSTS FOTOPOLIMĒROS UZ AKRILĀTA PAMATA}

\section{J. Aleksejeva, J. Teteris}

\section{Kopsavilku ms}

Šajā darbā pētīta tilpuma režğu veidošanās hologrāfiskā ieraksta laikā Norland Optical Adhesive fotopolimēros uz akrilāta pamata. Hologrāfiskais ieraksts veikts ar He-Cd lāzera $325 \mathrm{~nm}$ līniju, kura laikā ierakstīti tilpuma režği. Režğa veidošanos fotopolimēros var izskaidrot ar fotopolimerizācijas procesu UV gaismas ietekmē. Pētīta difrakcijas efektivitāte transmisijas režīmā atkarībā no parauga biezuma, ierakstošo staru intensitātes un polarizācijas. Parauga biezuma palielināšana l̦auj iegūt režğus ar labāku leņksisko selektivitāti, tāpēc paraugi tika gatavoti ar biezumu līdz 2,4 mm. Šajā darbā difrakcijas efektivitāte tika iegūta virs $80 \%$, bet labāka leņkiskā selektivitāte sastādīja dažas grāda minūtes. Šādus režğus ar augstu difrakcijas efektivitāti un labu leņķisko selektivitāti veiksmīgi var izmantot telekomunikācijās. Šo režğu priekšrocības ir ilgstoša mehāniskā noturība, zema atkarība no temperatūras izmaiņām, vienkārša un lēta izgatavošana. 